\title{
Comparing MFS in Kenya, Philippines and South Africa under 7 P Evaluation Framework
}

\author{
Shalu Chopra \\ Department of Information \\ Technology \\ VES Institute of Technology \\ Chembur, Mumbai, India
}

\author{
Richa Sharma \\ Department of Information \\ Technology \\ VES Institute of Technology \\ Chembur, Mumbai, India
}

\author{
Arun Mohan Sherry, Ph.D \\ Centre for Distance Learning \\ Institute of Management \\ Technology \\ Ghaziabad, UP, India
}

\begin{abstract}
Mobile financial services has brought a revolution in developing nations. More and more people from the rural areas are now using financial services provided by mobile phones. Though still in its infancy its potential is tremendous. Mobile payment services have made it easy $\mathrm{n}$ cost effective to transfer money from one corner of the world to another improving the lives of many underprivileged worldwide. Different Payment systems by different providers are available in different developing nations. However the success of few mobile payment systems - like M-Pesa of Kenya, GCash and SmartMoney of Philippines and WIZZIT and MTN of South Africa are unprecedented. In spite of their cultural, social and economic differences, Mobile payment has been widely accepted and used in these countries. In this paper we have studied these successfully implemented paymentsystem around proposed a $7 \mathrm{P}$ evaluation framework.
\end{abstract}

\section{General Terms}

Mobile financial Service, M-Payment, Mobile Network Operator

\section{Keywords}

MFS, M-Pessa, G-CASH,WIZZIT

\section{INTRODUCTION}

Today providing financial services to underprivileged is the biggest challenge faced by the developing nations as their transactions are generally small and many live in remote areas beyond the reach of banks or ATM networks.[1] .Mobile banking can be seen as one solution to these problems. Mobile financial services like mobile banking, mobile payment and mobile microfinance have made it possible to integrate people in the rural area with the traditional banking system at a reasonable cost[1]. The technology is no doubt the cheapest and most convenient way to connect people and provide array of innovative services.

Mobile subscribers in donor countries can transfer cash directly from their mobile phone, across international borders, to the mobile wallet of family and friends, wherever they may be. With over 4 billion mobile cellular subscriptions worldwide, mobile network has the ability to immediately offer mobile banking to $61 \%$ of the world [Wireless intelligence, 2009].

This paper begins with overview of mobile financial services . Section 2 defines a $7 \mathrm{P}$ evaluation framework which is based on 7 parameters Product, Process, Privacy, Pros, Problems, Price and Policy \& Regulation. Section 3 discusses successfully implemented mobile payment system like MPessa of Kenya, G-Cash and SmartMoneyof Philippines and Wizzit of South Africa around the 7P framework. Section 4 talks about the impact of m-payment, section 5 discusses
Learning from the existing systems and Section 6 is conclusion.

\section{MOBILE FINANCIAL SERVICE}

Mobile financial services can be defined as services using telecommunications network (or some NFC technology) on a mobile handheld device to carry out banking affairs and other forms of payments such as person-to-person, local and remote payments and using the handheld device for authentication purposes. MFS is dependent on three key parties: [6]

- The wireless carriers, or mobile network operators (MNOs)

- $\quad$ Financial institutions (FIs)

- Platform provides that act as the "glue" between the MNOs and the FIs.[6]

MFS services fall into one of three categories:

- mobile payments (P2P, C2B, or B2B)

- mobile microfinance (loan disbursement and payments)

- mobile banking (account information, e.g. balances or alerts, remittance)

\section{7 P FRAMEWORK}

The 7P framework constitute of 7 features on the basis of which mobile payment systems are evaluated.

\subsection{Product}

Product describes the service provider, technology platform, delivery model (for example bank-led or MNO-led), product features and characteristics; and any unique aspects.

\subsection{Process}

Processes refer to the methods of subscribing to the service and using the product. It also talks about payment collection centres, network operators and banks involved.

\subsection{Privacy}

Privacy is about the various features/options present to ensure security of transactions. It also includes aspects like security features or other measures in case of theft, fraud or other losses.

\subsection{Pros}

Pros discusses the upside or the positive impact of the mobile payment services from both clients and the provider's prospective e.g. outreach, accessibility, safety, time consumption, revenue generation etc. 


\subsection{Problems}

Problems focuses on the hurdles like technology barriers, consumer and channel illiteracy, technology and user interface complexities, human errors, liquidity management and lack of stable regulatory environment.

\subsection{Price}

Price talks about the direct costs of using the service such as enrolment charges, transaction charges (deposit and withdrawal, and other aspects like minimum and maximum transaction limits, hidden charges and so on.

\subsection{Policy \& Regulations:}

This covers aspects such as KYC norms, regulatory provisions for technology risk management and consumer protection. Also Anti Money Laundering / Combating Financing of Terrorism (AML/CFT) issues are discussed.

\section{CASE STUDY}

\subsection{M-PESA in Kenya}

The story of the growth of mobile telephony and mobile phone based financial services in Kenya, Africa, is unprecedented and has become a benchmark for every other mobile financial service or mobile money deployment around the world. From virtually unconnected in the 1990 's, over 60 percent of Africans now have mobile phone coverage, and there are now over ten times as many mobile phones as landline phones in use (Aker and Mbiti, 2010).

\subsubsection{Product}

Important features of M-PESA are

- $\quad$ Service provider -- Safaricom (60: $\underline{\text { Vodafone, } 40: \text { Telkom) }}$

- Technology solution provider -- Vodafone Group

- Partnering bank -- Commercial Bank of Africa

- $\quad$ Launch date -- Mar-07

- $\quad$ Banking model used -- $\underline{\mathrm{MNO}}$-led branchless banking model

- Hardware requirement -- $\underline{32 \mathrm{kSIM}}$

\subsubsection{Process}

At the core of M-PESA is a mobile wallet that holds the

\subsubsection{Process}

At the core of M-PESA is a mobile wallet that holds the electronic-float (e-float) for the consumer, which can be used to transfer to another M-Pesa account, make remote payments or exchanged for cash [14]. There are three basic transactions that customers conduct with M-Pesa

- A customer may deposit money at an M-Pesa outlet in return for e-float ("Cash-in"). The customer needs to show a valid identification, and deposit some amount. Upon receipt of the money, the M-Pesa agent enters the customer's telephone number and deposit information into his/her cell phone, and the customer waits until he/she receives a confirmation text (SMS \} message that e-float has been deposited

- A customer may exchange e-float for cash at an M-Pesa outlet ("Cash-out"). The customer chooses "withdraw cash" on the M-Pesa menu on his phone, enters the amount to be withdrawn (plus the relevant fee), and enters the agent number. The agent on receiving confirmation gives the appropriate amount of cash to the customer.
- Finally, a customer may transfer e-float from his/her phone to another phone by entering recipient's phone number and the amount to be transferred on his/her cellphone. The sender and recipient each receive a text message stating that e-float has been transferred.

The following figure1 shows the transaction system of Kenya

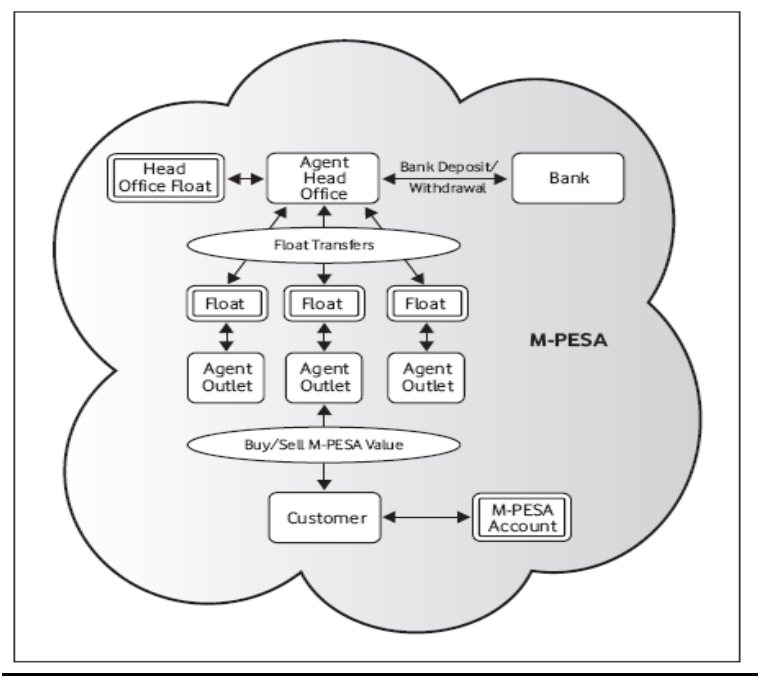

Fig 1 Transaction system of M-PESA [1]

\subsubsection{Privacy}

M-Pesa is safer than cash because a PIN is required to perform any transaction. If a phone is stolen or lost, the MPesa funds are safe unless the PIN has been compromised. If the PIN is compromised and funds are transferred to another account, the legitimate account holder can recover his/her funds if they have not been withdrawn by the fraudulent recipient by initiating a transfer reversal through the customer service department. MPESA comes with a full transaction tracking and reporting system, including customer care support and anti-money laundering measures.

\subsubsection{Pros}

M-Pesa money transfer services are quicker than alternative methods. The service enables its users to deposit and withdraw money quickly. Money transfer to other users and non-users also became easy. Users can pay bills, purchase airtime and pay merchants for purchases. They can also save money by using M-Kesho service and avail loan by M-Shwari service.

\subsubsection{Problems}

There are very few problems reported by M-Pesa :

- They have had problems in withdrawing money from an M-PESA agent, as the agent lack sufficient funds.

- Experienced problems retrieving money.

- Money was sent via M-Pesa to the wrong person by mistake and they were not able to retrieve their money.

- The charges for withdrawal and transfer are quite high, despite all the safety and convenience offered.

\subsubsection{Price}

M-Pesa is operated by Safaricom, a mobile network operator (MNO). 
- M-Pesa registration for an existing Safaricom customer is free, although a new Safaricom connection costs about $100 \mathrm{Ksh}$

- All M-Pesa deposits are free and so is buying airtime from M-Pesa wallet account.

- Balance inquiry cost $1 \mathrm{Ksh}$ and pin change cost $20 \mathrm{Ksh}$.

- There is no charge for depositing funds, but a sliding tariff is levied on withdrawals and on transfers (for example, the cost of withdrawing $\$ 100$ is about $\$ 1$ ).

- The overall transaction fee is far lower for sending to a registered user than to a non-registered user.[15]

\subsubsection{Policy and Regulations}

The growth in the mobile sector was primarily a result of the friendly regulatory environment the Kenya Communication Act $(\underline{\mathrm{KCA}})$ created in 1998. However, $\underline{\mathrm{KCA}}$ only regulates communications services; it does not regulate electronic commerce, mobile commerce, or mobile banking.Though Kenya's government did publish the ICT policy in 2006 and Electronic Transactions Bill of 2007 to address electronic commerce issues such as recognition of electronic transactions and electronic signatures, it has not enacted the Kenya Information and Communications Bill of 2007.The country still lacked a clear framework for electronic transactions, which it needed to participate effectively in the new internet economy. [16]

The following screen shot show the visual example of the process M-Pesa customer would go through while using the mobile-payment system

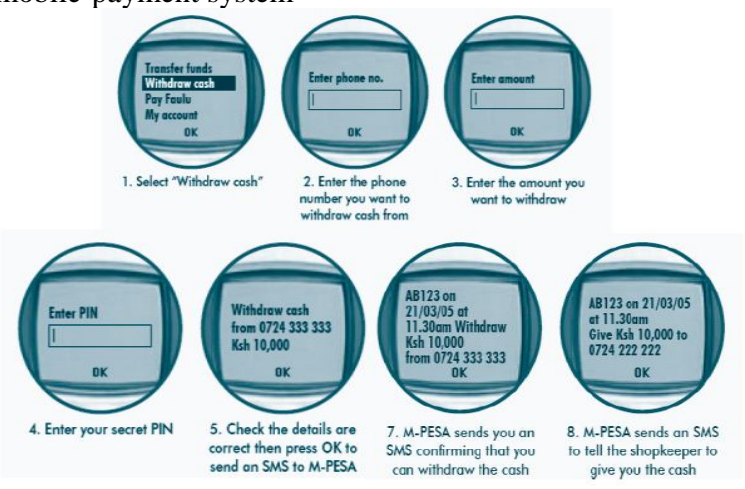

Fig 2. M-PESA Transaction screen shots [1]

\subsection{G CASH / SMARTMoney IN THE PHILIPPINES}

The Philippines has been consistently referred to as the texting capital of the world, with an estimated 200 million text messages sent a day in the country! (The Viability of Mobile SMS Technologies For Non-Formal Distance Learning In Asia, October 2005). SMS technology has particularly taken root in the Philippines because of the relatively low costs of purchasing a mobile phone, low cost of sending an SMS, (about US $\$$.02 cents per text) the limited availability of landline phones, and new government policies that have supported the expansion of the telecommunications sector. Currently about 40 percent of the population (about 33 million people) have a cell phone. Most of these are low cost "prepaid" accounts that allow users to "load" airtime for as little as US\$0.20.

\subsubsection{Product}

There are two wide spread mobile payment operators - Globe cash (G-Cash) from Globe Telecom and SmartMoney from Smart Communications.

- Service provider -- Globe Telecom/ SMART Communications

- Technology solution provider -- Globe Telecom/ SMART Communications

- $\quad$ Partnering bank -- Banco de Oro (BDO)

- $\quad$ Launch date -- Oct-1994/Dec-2000

- Banking model used - MNO led branchless banking model

- Hardware requirement -- 32k SIM

\subsubsection{Process}

$G$ - $C A S H$

G-Cash is basically an M-Commerce service. Transactions are not merely limited to money remittances. Registration process is one-time and SMS-based. G-Cash is a cardless service. Once registered, only a self-assigned mobile PIN and recipients' mobile number are required for transactions. Gcash publishes a list of keywords that users need to type to accomplish various transactions. Deployment is faster and cheaper.

\section{SmartMoney}

SmartMoney is run in partnership with Banco de Oro (BDO). It is a pre-paid re-loadable payment card linked to the SMART cell phone and the MasterCard electronic payment system. It has a menu based system to do transactions, Once loaded, it works like any other debit card.

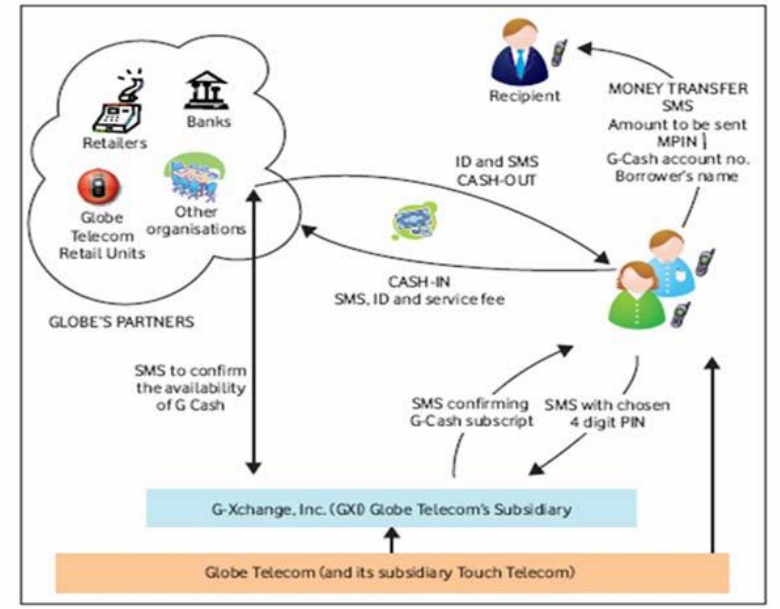

Fig 3. Transaction System of Globe Telecome [1]

\subsubsection{Privacy}

G-Cash has a PIN-locking process to keep the account secure. Subscribers can claim G-Cash at Business Centers if they lose their phone [12]. In SmartMoney, the mobile phone is coupled with a Cash Card that may be used to withdraw money via ATMs or pay for purchases, thus there is also a PIN associated with the card, for additional security. 


\subsubsection{Pros}

It is safer, convenient and a cheaper alternative method available for remittance. It also minimizes the risk of theft/robbery. For banks it increases revenues from new/additional fee-based services, it also increases revenues by taking advantage of and participating in remittance business.

\subsubsection{Problems}

- To sign-up for SmartMoney, one first needs to register through a Smart Menu or SMS. Then the consumers need to apply for a Smart Money Mastercard at the nearest Smart Wireless Center and present a valid ID. It may take up to 7 days for the card to arrive. This is a cumbersome process for the poor un-banked, as they might not have a permanent establishment or would find safe custody of the card a difficult proposition.

- One of the main disadvantages of the G-Cash system is that it has no high security features.

\subsubsection{Price}

G-Cash prices are as follows

- Money Transfer at an outlet or cash-out: Php 20 for every Php 1,000 or part thereof.

- $\quad$ Self initiated P2P transfer: Php 10 for every Php 1,000 or part thereof.

SmartMoney prices are as follows

- A one time subscription fee of Php 120.

- Self initiated P2P transfer: Php 5.0 for every money transfer transaction.

- $\quad$ Php 2.50 for balance and any other inquiry, reloading cash, paying bills

- $\quad$ Php 5.00 per Cash-out from BDO branch. Php 200.00 from ATMs and 1\% of transaction charge for cash-out at Smart stores.

\subsubsection{Policy and Regulations}

The Central Bank of the Philippines or Bangko Sentral ng Pilipinas (BSP) regulates electronic transactions as part of its mandate. BSP provides guidelines for electronic financial transactions, which evolve around issues of Technology Risk Management and Consumer Protection for Electronic Banking. Technology risk management involves ensuring the financial institutions have the requisite capacity to appreciate and manage the risks that emerge from deploying technologies to serve their customers. Consumer protection on the other hand focuses on safeguarding customer information, legal aspects of enforcing electronic transactions and agreements, while addressing Anti-Money Laundering and Combating Financing of Terrorism (AML/CFT) issues[15].

The following screen shots show the visual example of the process an G-Cash customer would go through while using the mobile-payment system.

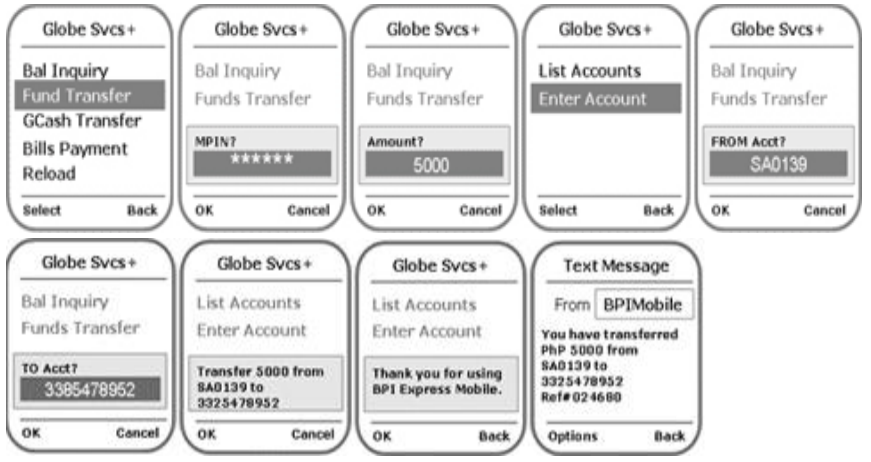

Fig 4. Screen for a G-CASH Transaction [1]

\subsection{WIZZIT/MTN Banking in South Africa}

WIZZIT was introduced in South Africa in November 2002 through a partnership with the South African Bank of Athens. WIZZIT has positioned itself as a virtual bank and has no branches of its own. Whereas, MTN Mobile Money was launched in South Africa in 2005 by MTN and has subsequently been acquired by Standard Bank and re-branded as MTN Banking. MTN Mobile Money was a joint venture between the country's second largest network operator MTN and a large commercial bank 'Standard Bank'.

\subsubsection{Product}

Mobile phone customers can use their phone to make personto-person payments, transfer money, purchase prepaid electricity, and buy airtime for a prepaid mobile phone (Kramer and Paul 2006: 12).

- $\quad$ Service provider -- WIZZIT/Standard Bank

- Technology solution provider -- Cointel-Simplus/ Fundamo

- Partnering bank -- Absa Bank, Postbank, Bank of Athens, Standard Bank

- $\quad$ Launch date -- Dec-04/Aug-05

- $\quad$ Banking model used -- Bank based model

- Hardware requirement -- 32k SIM

\subsubsection{Process}

\section{WIZZIT}

To open a WIZZIT bank account, a WIZZIT agent is sent to the applicant's home or workplace. Wizzit agents are called "Wizz Kids". At present the company employs over 2,000 of these "Wizz Kids" to promote the product in townships and rural communities and to help customers open accounts[1]. These Wizz Kids get commission for each new customer when they open account.

- Transactions for the WIZZIT service are initiated through a USSD short-code entered in a specific syntax including a combination of digits and symbols (* at the beginning and \# at the end).

- On sending this request, a menu appears in English on the customer's mobile phone, each of which requires entry of additional digits and symbols to choose options.

- Confirmation receipts are received by SMS. This service is available on any handset without explicit activation. 


\section{MTN Mobile Money - now MTN Banking}

Mobile Money starter packs are available via MTN agents and bank branches; and account opening takes place remotely through an interactive process during which voice recordings are taken as bio-metric identifiers and the Mobile Money menu is downloaded over the air to a 32k SIM card. Like Celpay, MTN Mobile Money uses Fundamo software platform. As of April 2005, Mobile Money reported 15000 clients. The following figure shows the transaction system of Wizzit

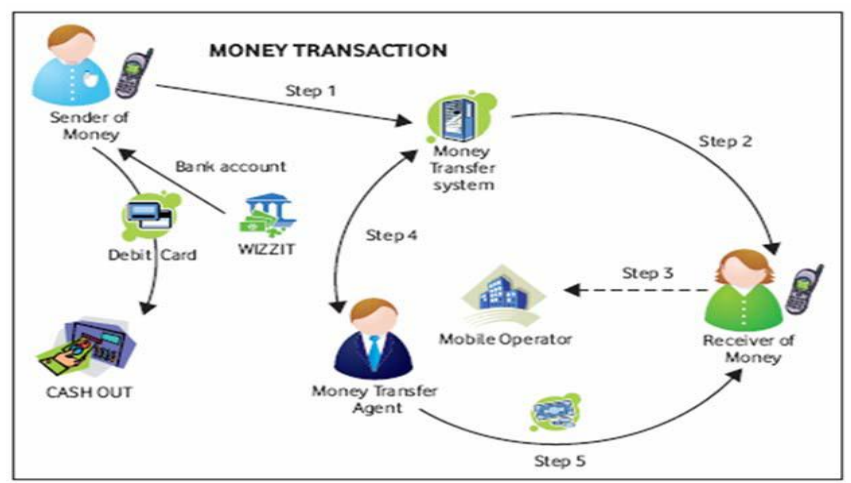

Fig 5.WIZZIT transaction system [1].

\subsubsection{Privacy}

Both the services provide complete end to end security. Besides SIM Encryption, PIN security and Voice Recognition is also used for security.

\subsubsection{Pro}

Customers feel that $\mathrm{m}$ payments services are affordable, easy to use, more secure, convenient and transaction like paying utility bills, money transfer, buyng airtime, checking account balance becomes very fast [1].

\subsubsection{Problems}

Many people in South Africa believe that:

- A large section of the population have difficulty with using technology, including mobile phones.

- People prefer to interact face to face with others rather than with electronic devices.

- Underprivileged people believe that their income and employment status render them ineligible to have banking services [1]

\subsubsection{Price}

Following are the price features

- There are no hidden costs.

- There are no registration charges.

- Minimal charges are taken for remittance.

- Maximum transaction limit is ZAR 1,000 per day

\subsubsection{Policy \& Regulations}

The Financial Intelligence Center Act (FICA) and its regulations govern anti-money laundering.

\section{Impact of MFS}

MFS has changed lives of many people worldwide. Within eight months of its inception in March 2007, over 1.1 million Kenyans had registered to use M-Pesa, and over US $\$ 87$ million had been transferred over the system (Safaricom, 2007). By September 2009, over 8.5 million Kenyans had registered to use the service and US $\$ 3.7$ billion (equivalent to 10 percent of Kenya's GDP) had been transferred over the system since inception (Safaricom, 2009). Figure below illustrates how Kenyan households sent money before and afterM-PESA [FSD-Kenya (2007a and 2009a)].

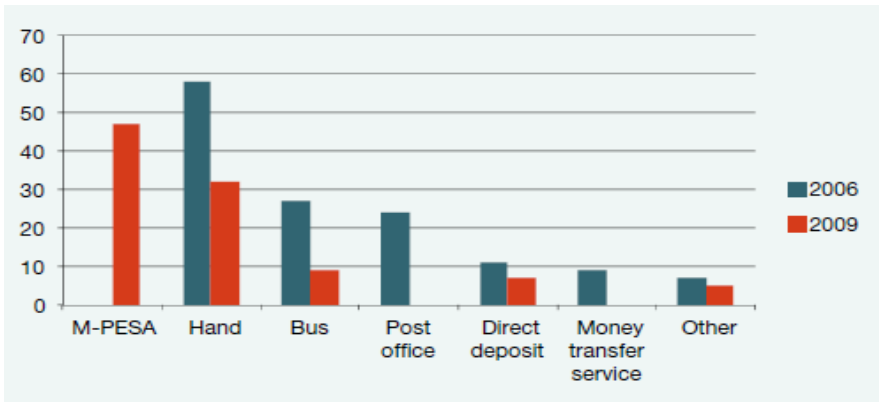

Fig 6. How people in Kenya sent money before and after M-PESA [14]

This explosive growth was also mirrored in the growth of MPesa agents (or service locations), which grew to over 18,000 locations by April 2010, from a base of approximately 450 in mid-2007 (Safaricom 2009 and Vaughan, 2007.By contrast, Kenya has only 491 bank branches, 500 postbank branches, and 352 ATMs (Mas and Ng'weno, 2009). Currently Safaricom has about 65,000 M-Pesa agents around Kenya servicing over 17 million users (Safaricom 2013).

In Philippines as of March 2006, there are approximately 1.3 million G-cash registered users and 282,000 active users who have made transactions in the past 3 months. Roughly US\$267 million have passed through the G-cash system since inception. In addition, there is now a vast distribution network of 700,000 airtime loading retailers throughout the country[18].

In south Africa, before 2004, 13 million South Africans hiding 12 billion Rands under their mattress. Since 2004, WIZZIT has offered South Africans a low-cost, transactional bank account that uses any cell phone on any network for making and receiving payments, together with a MasterCardbranded debit card which can also be used at ATMs and point-of-sale devices. Over 400,000 people in the country have opened accounts with WIZZIT[19].

\section{LEARNINGS}

M-PESA of Kenya and GCASH of Philippines is an MNO led model where Telecom Company has a hold on MFS services. Countries where bank penetration is low can adopt these model. M-PESA does not pay any interest on deposits to its account holders, nor does it offer any loans. M-PESA, hence, is primarily a payment mechanism. G-Cash service is an emoney account tied to a mobile phone subscriber information module (SIM card). The account can be loaded and unloaded by depositing or withdrawing cash at a wide range of retail agents and the mobile operator's own dealers. Inspite of its 
success, the model is fraught with many operational risks which has the potential to derail the system.

WIZZIT is an Bank Led model. The South African Reserve Bank has given operative discretion to the Banks in engaging agents. However, they have kept the whole system under tight regulation to minimize operational risk and safeguard the interest of the customers. This has helped the Banks to take initiatives in developing innovative models. The Banks are made solely responsible for the internal management systems and procedures of the outsourcing agents. Countries which have good banking infrastructure can opt for this model.

\section{CONCLUSION}

Although it is in its infancy, a growing number of mobile financial services are being piloted in different parts of the world, and there are great hopes for the transformational potential of mobile transactions. Just as mobile communications present a prime case for leapfrogging traditional infrastructure, so too does the mobile financial service industry have the potential to extend the provision of financial services to people through a technology that is both familiar and widespread. There are few, yet very visible and successful experiences of mobile financial services in developing countries, suggesting that mobile financial services have great potential for the unbanked population. These services have been studied in detail using the $7 \mathrm{P}$ evaluation schema. The schema serves as guidelines for understanding the working and features of successful payment systems in different countries and provides guidelines to successfully implement them in other developing nations.

Mobile financial services clearly have great potential to revolutionize the provision of financial services to a large portion of the developing world's population that currently lacks such services. Also the promise of mobile financial systems suggests that this innovative approach will likely become a dominant feature of the financial landscape in much of the developing world.

\section{ACKNOWLEDGMENTS}

We would like to thank department of Information Technology of Vivekanand Education Society's Institute of Technology (VESIT) for providing us opportunity to carry out our work.ur thanks to the experts who have contributed towards development of the template.

\section{REFERENCES}

[1] Alaina McMurray "Mobile Financial Services: Extending the Reach of Financial Services Through Mobile Payment Systems” FDC 2009

[2] Sanjeev Bansal " Mobile Banking \& M-Commerce and Related Issues”
[3] Juniper Research "White paper Mobile Banking goes Mainstream extract from Mobile banking Strategies, Application, Opportunities and Markets” 2010-2015

[4] Dr. Prof Eduard Heindl Elham Ramezani "Mobile Payment E- Business Technology" (2008)

[5] Rasheda Sultana "Mobile banking: Overview of Regulatory framework in emerging markets"

[6] David Porteous "The Enabling Environment for Mobile Banking in Africa, Report Commissioned by Department for International Development (DFID)" Bankable Frontier Associates 2006

[7] William Jack, Tavneet Suri "Mobile Money: The economics of M-PESA" Working Paper 16721 National Bureau of Economic, January 2011

[8] Isaac Mbiti, David N. Weil "Mobile Banking: The Impact of M-PESA in Kenya" Working Paper 17129 , National Bureau of Economic, June2011

[9] John Owens, Anna Bantug-Herrera "Catching the Technology Wave: Mobile, Phone Banking and Text-aPayment in the Philippines"

[10] "Mobile Financial Services Working Grou (MFSWG): Guideline Note Basic Terminology" CGAP July 2012

[11] Globe Telecom "Reducing Transaction Costs to Extend Access: New Technology" CGAP Annual Meeting 2005

[12] Tonny Omwansa "M-PESA: Progress and Prospects Innovations Case Discussion: M-PESA" Innovations / Mobile World Congress 2009

[13] Finaccess. 2007. Financial access in Kenya: Results of a 2006 national survey. Nairobi.

[14] Ignacio Mas and Dan Radcliffe, 2011"Mobile Payment go viral : M-PESA in Kenya" The Capco Institute journal of financial Transformation, Aug 2011

[15] www.en.wikipedia.org/wiki/

[16] www.safaricom.co.ke/personal/m-pesa/m-pesa-servicestariffs/tariffs

[17] Donner, Jonathan and Tellez, Camilo Andres (2008) 'Mo bile banking and economic development: linking adoptio n, impact, and use', Asian Journal of Communication $(18,4: 318-332)$

[18] John Owens \& Anna Bantug-Herrera, 2006 "“Catching the Technology Wave: Mobile Phone Banking and TextA-Payment in the Philippines".

[19] IFC, 2011, "Stories from the fields-WIZZIT Microlending Pilot (South Africa) Mobile Banking Access for the unbanked", International Finance corporation 